\title{
Causes of Costs Overrun in Road Construction Project in Oman
}

\author{
Osama Salim Al Adawi ${ }^{1}$ and Hussin A.M Yahia ${ }^{1 \#}$ \\ ${ }^{1}$ Department of Civil Engineering, Middle East College, Knowledge Oasis Muscat, Sultanate of Oman \\ \#Advisor
}

\section{$\underline{\text { ABSTRACT }}$}

Cost overrun is a common phenomenon in construction projects of any country, be it in developing or developed countries. This issue is a critical issue that impacts a project's success. It, therefore, needs serious attention from all the participants in the construction project to keep the projects in safe mode, to be completed within its limited cost, time, and performance. Cost overrun has a negative impact on construction project performance, which is because the construction industry is vast and complex. Any difficulty occurring during the project's life cycle leads to other problems in various parts of the project. Studies by many researchers' cost overruns by literature review, and according to their studies suggested the most cost overrun causes. The aim of this study is to identify the most critical factors leading to cost overruns on road projects in Oman, and then provide suggestions to resolve them.

\section{Introduction}

Construction industry has been defined as a unique business considering that its deliverables, products and activities are site-specific (Hampson and Perera 2018). It has become a dynamic player in the economy growth of any country, mainly the developing countries (Ahady et al. 2017). As stated by Ansar et al. (2016), there is a common belief in the economics' literature of a relation between growth of economy and amount of investments in infrastructure's projects. Recently, construction sector has been considered as one of the leading industries in the World (Vaardini et al. 2016). It is the second largest industry in Gulf countries that continuously and swiftly growing (Imran Latif et al. 2019). Also, it improves the quality standard of living through the development of roads' network, hospitals and hotels (Al-Emad et al. 2016).

In Oman, construction industry plays an active role in developing Oman's economy (Albalushi et al. 2013). Recent years, Oman has recorded a significant growth in construction industry (Saleh and Alalouch 2015) and expected to achieve 6\% CAGR (Compound Annual Growth Rate) from 2019 to 2024 (Mordor Intelligence 2019). As reported by Anon. (2020), construction value of buildings expected to hit OMR 3.9 bn. in 2024 in Oman.

However, as constructions' business grows, challenges remain. Globally, construction projects are confronting challenges to control projects' costs and always experience costs overrun (Bentil et al. 2017). Complex in nature and fragmented, therefore, construction industry is always fronting critical challenges with costs overrun (Matin 2016). It occurred when the difference between the originally estimated costs of a project varied from the actual cost when completing that project (Amoa-Abban and Allotey 2014). Next section will present an overview of costs overrun in construction industry.

\section{Roads Constructions and Costs Overrun in Oman}

Construction of roads network is continuing to grow in Oman. According to Oman's National Center for Statistics and Information, the length of completed asphalt road in Oman is $39,430 \mathrm{~km}$ in 2018 which increased about $7 \%$ 
compared to 2016 (NCSI 2020). Different tenders of roads' projects floated by Ministry of Transport in 2019 including the construction of Phase 3 for Adam-Thurmont road with a length of $132.5 \mathrm{~km}$ and construction of Phase 1 for Rusayl-Bidbid with a length of $27 \mathrm{~km}$ which connects Muscat Expressway with Al Sharqiyah Expressway (Oommen, A. 2019). Recently, Ministry of Transport (MOT) opened Al Sharqiyah Expressway, Package 1 to the traffic. The Expressway connects BidBid with Al Kamil W'al Wafi which stretched over $191 \mathrm{~km}$ and includes major structures like viaducts that at height up to $90 \mathrm{~m}$ and two tunnels (Nair 2020).

Also, MOT conducted a study on roads network development to be able prepare a master plan for developing and upgrading primary and secondary roads network from 2006 to 2030. The projected growth of roads network is captured in Figure 1.1

Growth of Road Network in Oman

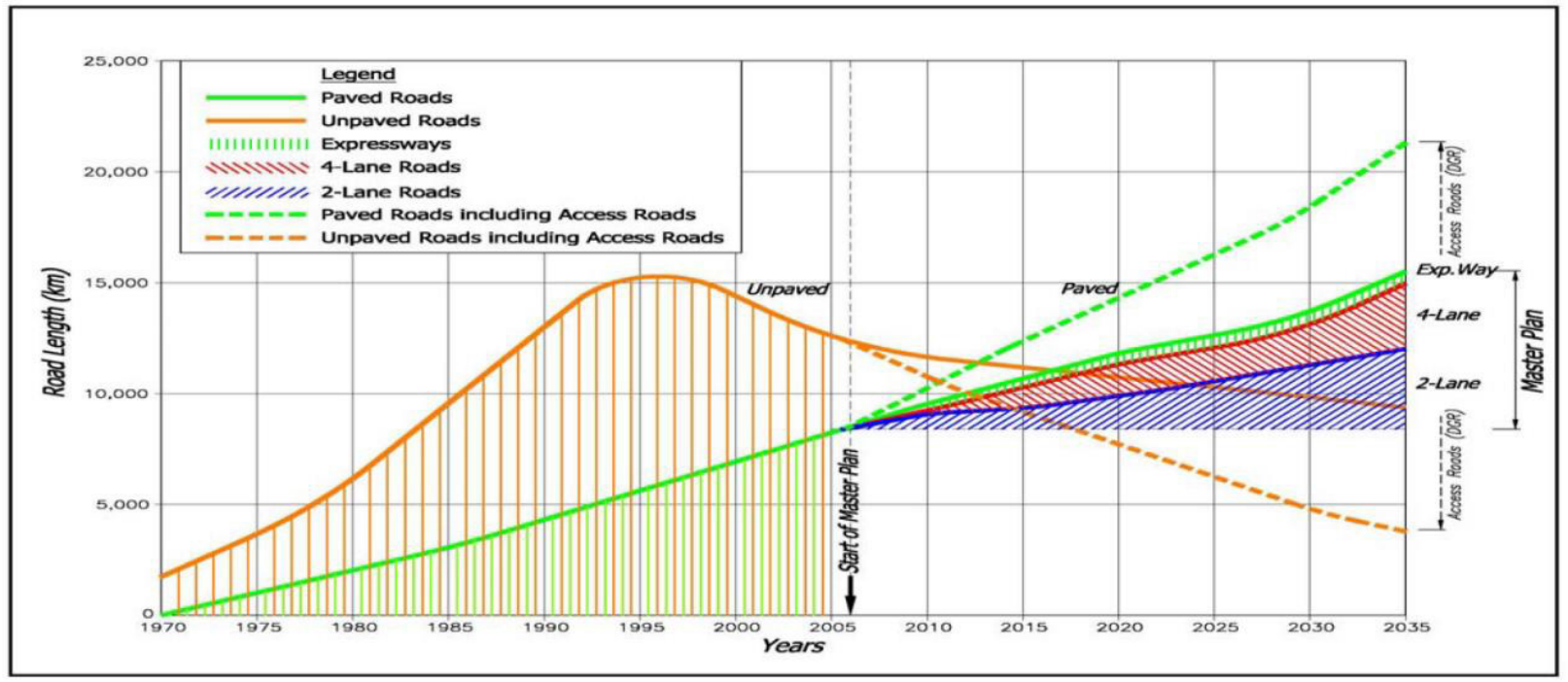

Figure 1.1 Growth of Road Network in Oman (JICA 2006)

The chart indicates that there are a lot of projects are coming in the pipeline next 15 years in which will make it crucial to optimize the construction performance of roads' projects and find remedial strategies for the costs overrun issues. Giving that, there are no studies conducted on costs overrun in roads construction for Oman, therefore, understanding the reasons for the same is important. Studying costs overrun causes is required to understand most critical ones and accordingly be able to offer recommendations for Ministry of Transport and other concerned parties in Oman. Hence, this research sought to identify the causes of costs overrun in roads' construction projects in Oman and critically analyses them to find most critical ones in a try to present effective remedial strategies

\section{Methods}

Any research data normally collected from two types of sources which are primary and secondary in which primary will be collected directly from respondents and secondary from literatures, web and documents (Greener 2008). According to Kothari (2004), primary data are freshly collected through different methods like interviews and questionnaires for the first time and accordingly occur to be unique in character. Whilst the secondary data are collected from sources like journals and reports. Both primary and secondary data were utilized in this study. 


\section{Primary Data}

The primary data are those collected for a specific purpose or for a research study (Erickson 2017; Srivastava and Rego 2008). For this research, the primary data were collected via a questionnaire. The required sample size for this study was 113 which represented the 160 targeted population.

\section{Secondary Data}

Secondary data are the data that already available which has been gathered and analyzed by someone else (Kothari 2004). Secondary data for this research are recent journals, books, conference proceedings, dissertations, newspapers, handbooks, reports, and documents obtained from different

\section{Results and Discussion}

Lohr (2009) recommended that, response rate statistics and elements should be published in the research reports and readers should be given explanations of responses rates used, covering actual counts, and annotation on the relevance of response rate to the quality of the questionnaire data. The questionnaire of this study was distributed online via different means like emails and WhatsApp. Once the questionnaires distribution process commenced, it was noticed that the responses are very low. Hence in order to encourage respondents to complete the questionnaires, follow-up phone calls, emails and messages were made to improve the response rate. The period of distribution process spanned from 21 st June 2020 to 28 th July 2020. Based on the required sample size, which is 113 , it was decided to distribute a set of 113 questionnaires to the roads' professionals as following patterns: 40 for client, 35 for consultants and 38 for contractors.

Table 1.1 the Numbers of Planned and Returned Questionnaires and their Response Rates

\begin{tabular}{|l|l|l|l|l|}
\hline $\begin{array}{l}\text { Surveyed Organiza- } \\
\text { tion }\end{array}$ & $\begin{array}{l}\text { Questionnaires } \\
\text { Planned }\end{array}$ & $\begin{array}{l}\text { Questionnaires } \\
\text { turned }\end{array}$ & $\begin{array}{l}\text { Re- } \\
\text { naires Response Rate }\end{array}$ & $\begin{array}{l}(\%) \text { of Returned from } \\
\text { Total }\end{array}$ \\
\hline Client & 40 & 31 & 50.77 & 36.47 \\
\hline Consultant & 35 & 72 & 41.77 & 31.76 \\
\hline Contractor & 38 & 27 & .0071 & 31.76 \\
\hline Total & 113 & 58 & 22.75 & 100 \\
\hline
\end{tabular}

Above Table shows that from a total of 113 distributed questionnaires, 85 responses are received. These are $31(77.50 \%)$ from the client, 27 (77.41\%) from consultants and $27(71.00 \%)$ from contractors. The total response rate is $75.22 \%$. It can be noticed that responses from contractors were the lowest comparing to client and consultants. This is apparently due to the consequences of COVID-19 as many roads' professionals whom workingfor contractors were unreachable, many employees were shoveled between different site camps and construction firms are going through a rearrangement process of their work environment and the way they do businesses.

\section{Demographic Analysis -}

General demographic characteristics on the respondents have been surveyed for this study, e.g. gender, age, nationality, organization type, work experience, respondent designation, and educational level. In general, the results revealed that majority of respondents are males with a percentage of $83.5 \%$ of which $40 \%$ of them are within $25-35$ years old. 
In the other hand, females constitute $16.5 \%$ of the samples of which $14.1 \%$ of them are within $25-35$ years old. Large proportion of the respondents are young adults with an age range of 25-35 years old and middle-aged adults with an age range of 36-46 years old. The respondents aged from $47-57$ represent $11.8 \%$ of the total samples while those below 25 years old form only $1.2 \%$.

Table 1.2 shows cross tabulation results of the respondents' gender and ages.

\begin{tabular}{|c|c|c|c|c|c|c|c|}
\hline \multirow{2}{*}{$\begin{array}{l}\text { Age } \\
\text { Gender }\end{array}$} & & \multicolumn{5}{|c|}{ Ages (\% of Total) } & \multirow[b]{2}{*}{ 7Total } \\
\hline & & $\begin{array}{l}\text { Under } \\
\text { years old }\end{array}$ & \begin{tabular}{l|l}
25 & $25-35$ \\
old
\end{tabular} & $\begin{array}{c}\text { years } 36-46 \\
\text { old }\end{array}$ & \begin{tabular}{c|c} 
years & $47-57$ \\
old
\end{tabular} & $\begin{array}{l}\text { years } \begin{array}{l}\text { Above } \\
\text { years old }\end{array}\end{array}$ & \\
\hline \multirow[t]{2}{*}{ Gender $(\%$ ofTotal } & Male & $0.0 \%$ & $40.0 \%$ & $22.4 \%$ & $11.8 \%$ & $9.4 \%$ & $83.5 \%$ \\
\hline & Female & $1.2 \%$ & $14.1 \%$ & $1.2 \%$ & $0.0 \%$ & $0.0 \%$ & $16.5 \%$ \\
\hline \multicolumn{2}{|l|}{ Total } & $1.2 \%$ & $54.1 \%$ & $23.5 \%$ & $11.8 \%$ & $9.4 \%$ & $100.0 \%$ \\
\hline
\end{tabular}

SPSS 24.0 was also used for calculating central tendency values "mean", "median" and "mode" to understand where the most responses are centralized and confirm the most frequently observed scores (Mcintyre 2009). These values were determined to know the most frequently observed costs overrun causes and confirm with the results obtained by RII technique. As would be expected, though some causes have very high impact on developing costs overrun. Based on the results, the RIIs can be classified into three categories as follows: causes with very high impact with RII above 0.700 , causes with average to high impact with RII lying between 0.600 and 0.700 , and causes with very low to low impact with RII less than 0.600. Table 3 lists the RIIs and ranking of the very-high-impact (most critical) costs overrun causes together with their central tendency values "mean", "median" and "mode."

The full list of the ranked causes with their RIIs is provided in illustrated in the radar diagram of Figure 2. The number between brackets in the (Rank) column corresponds the sequential ranking, as some of causes have same RIIs as in the case of row 2 and row 3.

Table 1.3 Very High Impact (Most Critical) Costs Overrun Causes with their RIIs, Ranking andCentral Tendency

\begin{tabular}{|c|c|c|c|c|c|c|}
\hline \multirow[t]{2}{*}{ Group } & \multirow[t]{2}{*}{ Cost Overrun Causes } & \multirow[t]{2}{*}{ RII } & \multicolumn{3}{|c|}{ Central Tendency } & \multirow[t]{2}{*}{ Rank } \\
\hline & & & Mean & Median & Mode & \\
\hline Client-Related & $\begin{array}{l}\text { Contractors are not paid on } \\
\text { time (overdue/delay payments) }\end{array}$ & 0.816 & 2.45 & 3.00 & 3.00 & $1(1)$ \\
\hline Design-Related & $\begin{array}{l}\text { Incomplete design at the time } \\
\text { of tender }\end{array}$ & 0.780 & 2.34 & 3.00 & 3.00 & $2(2)$ \\
\hline Design-Related & Design errors & 0.780 & 2.34 & 2.00 & 3.00 & $2(3)$ \\
\hline $\begin{array}{l}\text { Contractor- } \\
\text { Related }\end{array}$ & Cost underestimation & 0.776 & 2.33 & 3.00 & 3.00 & $3(4)$ \\
\hline Client-Related & Funding difficulties & 0.769 & 2.31 & 2.00 & 3.00 & $4(5)$ \\
\hline Client-Related & Slow decision-making & 0.761 & 2.28 & 2.00 & 2.00 & $5(6)$ \\
\hline $\begin{array}{l}\text { Contractor- } \\
\text { Related }\end{array}$ & Time underestimation & 0.761 & 2.28 & 2.00 & 3.00 & $5(7)$ \\
\hline Design-Related & $\begin{array}{l}\text { Design changes due to faultydesign } \\
\text { during construction }\end{array}$ & 0.757 & 2.27 & 2.00 & 3.00 & $6(8)$ \\
\hline $\begin{array}{l}\text { External } \\
\text { Related }\end{array}$ & Corona Virus COVID-19 & 0.757 & 2.27 & 3.00 & 3.00 & $6(9)$ \\
\hline Client-Related & Improper project planning & 0.753 & 2.26 & 2.00 & 2.00 & $7(10)$ \\
\hline
\end{tabular}




\begin{tabular}{|c|c|c|c|c|c|c|}
\hline Design-Related & Uncontrolled design changes & 0.753 & 2.26 & 2.00 & 2.00 & $7(11)$ \\
\hline Client-Related & $\begin{array}{l}\text { Time underestimation for } \\
\text { completing the project }\end{array}$ & 0.749 & 2.25 & 2.00 & 2.00 & $8(12)$ \\
\hline $\begin{array}{l}\text { Other } \\
\text { Stakeholders-Related }\end{array}$ & $\begin{array}{l}\text { Slow decision-making by various } \\
\text { project's stakeholders }\end{array}$ & 0.741 & 2.22 & 2.00 & 2.00 & $9(13)$ \\
\hline $\begin{array}{l}\text { External } \\
\text { Related }\end{array}$ & $\begin{array}{l}\text { Unforeseen soil and physical } \\
\text { terrain conditions }\end{array}$ & 0.733 & 2.20 & 2.00 & 2.00 & $10(14)$ \\
\hline Design-Related & $\begin{array}{l}\text { Inadequate ground } \\
\text { investigations }\end{array}$ & 0.729 & 2.19 & 2.00 & 2.00 & $11(15)$ \\
\hline $\begin{array}{l}\text { Contractor- } \\
\text { Related }\end{array}$ & $\begin{array}{l}\text { Funding difficulties faced by } \\
\text { contractors }\end{array}$ & 0.722 & 2.16 & 2.00 & 3.00 & $12(16)$ \\
\hline Client-Related & $\begin{array}{l}\text { Right of Way and land } \\
\text { acquisition issues }\end{array}$ & 0.710 & 2.13 & 2.00 & 2.00 & $13(17)$ \\
\hline $\begin{array}{l}\text { Other Stakeholders- } \\
\text { Related }\end{array}$ & $\begin{array}{l}\text { Late requests by various project's } \\
\text { stakeholders such as utilities and } \\
\text { other concerned } \\
\text { authorities }\end{array}$ & 0.710 & 2.13 & 2.00 & 2.00 & $13(18)$ \\
\hline
\end{tabular}

*Averages of Central Tendency 2.26- 2.22- 2.50

The below diagram shows a full set of the ranked cost overrun causes and their RIIs. The RII valuecan be read through the grid lines which connect each ranked cause with the correspond built-in point that represents the RII value. For example, the built-in point of Cause (42) falls in the radar line with RII value of 0.600 exactly. Hence it can be observed from the diagram that most of causes are within the range of average impact to very high impact according to the range. Conforming to this observation, the averages of central tendency values shown in Table 21 


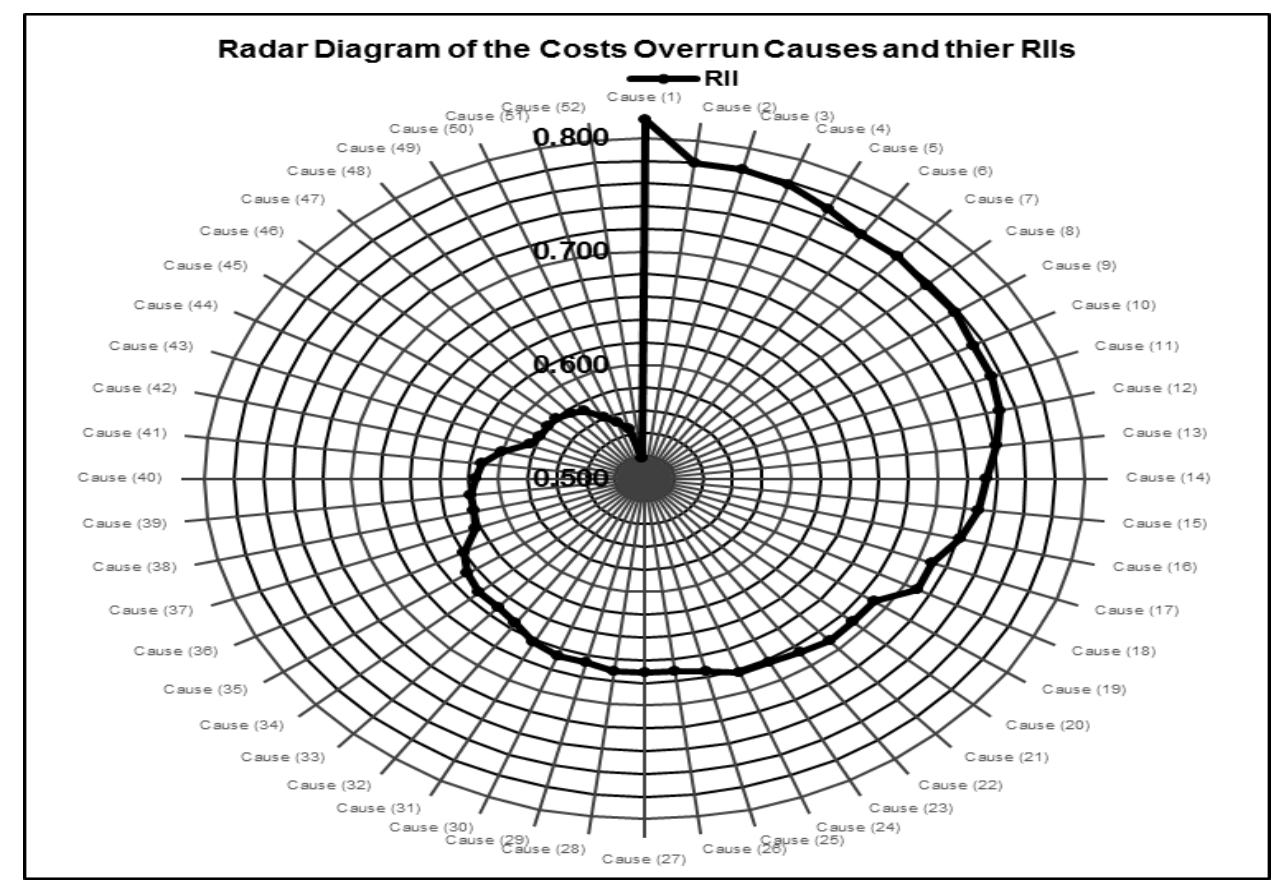

above also indicate that most frequent scores are between medium effect (scale $=2$ ) to high effect (scale $=3$ ) with an average central tendency of 2.26, 2.22 and 2.50 for mean, median, and mode, respectively.

Figure 1.2 Radar Diagram Showing the RIIs and Rankings of the Costs Overrun Causes

Causes of costs overrun are varied from country to country depending on construction nature, policies and regulation of each area. In this research 18 costs overrun causes in roads' projects within the Sultanate were found to be the most critical among the 52 causes which identified for the questionnaire. Several sources are responsible of these causes which can be categorized into five as follows: client, design, contractor, external and stakeholders. The responsible party of each cause can be identified case by case after the overrun source is identified. There might be causes of which the client takes the full responsibility, while responsibilities of some causes are shared between client and consultant. All above considered, a responsibility matrix has been derived from the above findings for each factor of costs overrun as presented in Table 1.4 .

Table 1.4 Responsibility Matrix of Costs Overrun Causes

\begin{tabular}{|c|c|c|c|c|c|c|}
\hline No. & Costs Overrun Causes(Very High Impact) & $\frac{\overrightarrow{0}}{\stackrel{\vec{\theta}}{u}}$ & $\begin{array}{l}\vec{\Xi} \\
\stackrel{\Xi}{\Xi} \\
\vec{\Xi} \\
0 \\
0\end{array}$ & 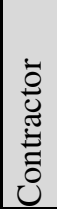 & 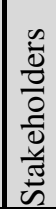 & $\begin{array}{l}\overrightarrow{\tilde{D}} \\
\text { ह } \\
\text { है } \\
\text { ठ } \\
0\end{array}$ \\
\hline 1 & Contractors are not paid on time (overdue payments) & $x$ & & & & \\
\hline 2 & Incomplete design at the time of tender & $x$ & $x$ & & & \\
\hline 3 & Design errors & $x$ & $x$ & & & \\
\hline 4 & Cost underestimation & & & $x$ & & \\
\hline 5 & Funding difficulties & $x$ & & & & $x$ \\
\hline
\end{tabular}




\begin{tabular}{|c|c|c|c|c|c|c|}
\hline 6 & Slow decision-making & $x$ & & & & \\
\hline 7 & Time underestimation & & & $x$ & & \\
\hline 8 & Design changes due to faulty design during construction & $x$ & $x$ & & & \\
\hline 9 & Corona Virus COVID-19 & $x$ & $x$ & $x$ & $x$ & $x$ \\
\hline 10 & Improper project planning & $x$ & & & & \\
\hline 11 & Uncontrolled design changes & $x$ & $x$ & & & \\
\hline 12 & Time underestimation for completing the project & $x$ & & & & \\
\hline 13 & Slow decision-making by various project's stakeholders & $x$ & & & $x$ & \\
\hline 14 & Unforeseen soil and physical terrain conditions & $x$ & $x$ & $x$ & & \\
\hline 15 & Inadequate ground investigations & $x$ & $x$ & & & \\
\hline 16 & Funding difficulties faced by contractors & & & $x$ & & \\
\hline 17 & Right of Way and land acquisition issues & $x$ & & & & $x$ \\
\hline 18 & Late requests by various project's stakeholders & $x$ & & & $x$ & \\
\hline
\end{tabular}

\section{Conclusion}

The main objectives of this study are to identify the most critical causes of costs overrun inroads' projects within the Sultanate of Oman based on the issues that have been addressed and justified within the current construction management practices pursued by client, consultants, and contractorsin an attempt to come up with mitigation strategies for these issues. Accordingly, this study has investigated costs overrun phenomena in the construction industry, with a focus on road construction, through extensive literature reviews in global and local contexts as discussed of which aided in mapping causes that are responsible for poor cost performance. Along with that, local roads' professionals were engaged to understand and confirm the causes of costs overrun which are controlling road construction. The most critical causes of costs overrun inroads' projects within the Sultanate were identified and analyzed since not all causes have the same influence on roads' projects, a Relative Importance Index was used to segregate between them based on importance. The most critical 18 causes were identified and ranked by the overall respondents based on importance as these were found to have a very high impact on roads' projects with a Relative Importance of more than 0.700 . Each of critical cause was discussed thoroughly to be able later finding a practical mitigation strategy. The top five causes are as follows: contractors are not paid on time, incomplete design at the time of tender, design errors, cost underestimation and funding difficulties. Besides, the ranks of causes were confirmed by using Mean Value method. Along with that, the measure of central tendency was adopted to have an overview of the typical value for each critical cause by calculating the mean, median and mode. Results analysis showed close values of means, medians and modes of which indicated typical central values which confirmed the quality and the consistency of the collected information resulting in reliable findings. The averages of central tendency revealed that the 18 criticalcauses are within the range of medium to high impact. Furthermore, as these causes were classified into five groups, causes within client related group were found as the most critical ones where causesin external and other stakeholder groups were the least critical. The overall findings of this research met with previous studies conducted in the same area for different countries. A comparison was done between the results of this research and other countries of which indicated that roads' construction projects in UAE and Oman are suffering almost from the same critical cause.

\section{References}


1. Ahady, S., Gupta, S. and Malik, K. (2017) 'A Critical Review of Causes of Cost Overrun in Construction Industries in Developing Countries'. International Research Journal of Engineering and Technology 4 (3), 2550 $-2558$

2. Albalushi, I., Usman, F. and Alnuaimi, A. (2013) 'Construction Cost Overrun and Variations: Investigation on Its Causes and Consequences'. Australian Journal of Basic and Applied Sciences 7 (14), 311-323

3. Al-Emad, N. (2016) Structural Relationships Model of Delay Factors in Makkah Construction Industry. Unpublished Master thesis. Parit Raja: Universiti Tun Hussein Onn Malaysia.

4. Amoa-Abban, K. and Allotey, S. (2014) 'Cost Overruns in Building Construction Projects: A Case Study of a Government of Ghana Project in Accra'. Journal of Developing Country Studies 4 (24), 54-64

5. Anon. (2020) 'Construction industry; Engineering; Economic conditions; Target recognition; Market research; Infrastructure; Market segments; Trends; Cities'. Journal of Engineering,

6. Ansar, A., Flyvbjerg, B., Budzier, A. and Lunn, D. (2016) 'Does Infrastructure Investment Lead to Economic Growth or Economic Fragility? Evidence from China'. Oxford Review of Economic Policy 32 (3), 360390.Atlanta 20 April, 247

7. Bentil, E., Nana-Addy, R., Asare, E. and Fokuo-Kusi, A. (2017) 'The Level of Existence and Impact of Cost and Time Overruns of Building Construction Projects in Ghana'. Civil and Environmental Research 9 (1), 36-46

8. Erickson, G. (2017) New Methods of Market Research and Analysis. Cheltenham: Edward ElgarPublishing Limit

9. Hampson, A. and Perera, S. (2018) Contractual Procedures in the Construction Industry.7th edn.

10. Imran Latif, Q., Al Saadi, A. and Abdul Rahman, I. (2019) 'Identification of Delay Factor in Oman Construction Industry'. International Journal of Sustainable Construction Engineering Technology 10 (1), 34-45

11. Matin, D. (2016) 'Identifying the Effective Factors for Cost Overrun and Time Delay in Water Construction Projects'. Engineering, Technology and Applied Science Research 6 (4), 1062-1066

12. Mordor Intelligence (2019) Construction Sector in Oman (2019-2024). Gachibowli: Mordor Intelligence LLP

13. Nair, V. (2020) 191-km-long Sharqiyah Expressway opens for traffic [online] available from < https://www.omanobserver.om/191-km-long-sharqiyah-expressway-opens-for-traffic/ > [30 May 2020]

14. NCSI (2020) Monthly Statistical Bulletin - Volume 31. Unpublished booklet. Muscat: NCSI New York: Routledge

15. Oommen, A. (2019) Oman's Ministry of Transport to expand road networks [online] available from < https://www.constructionweekonline.com/projects-and-tenders/260599-omans- ministry-of-transport-toexpand-road-networks > [29 May 2020] 
16. Saleh, M. and Alalouch, C. (2015). Towards sustainable construction in Oman: Challenges \& Opportunities. 'International Conference on Sustainable Design, Engineering andConstruction'. held 10-13 May 2015 at Chicago. Amsterdam: Elsevier Ltd

17. SI Albrka, A Ismail, HAM Yahia, MA Ladin, (2014). Application of transyt-7f on signalized road junction networks in Shah Alam and Petaling Jaya. Jurnal Teknologi, Volume 69- Issue 2.

18. Vaardini, U., Karthiyayini, S. and Ezhilmathi, P. (2016) 'Study No Cost Overruns inConstruction Projects - A Review'. International Journal of Applied Engineering Research 11 (3), 356-363. 